\title{
Pengaruh Variasi Penambahan Bahan Aditif Consol SG terhadap Kuat Tekan Beton
}

\author{
Ira Fauzia ${ }^{1}$, Gusneli Yanti ${ }^{2}$, Shanti Wahyuni Megasari ${ }^{3}$ \\ Program Studi Teknik Sipil, Fakultas Teknik, Universitas Lancang Kuning \\ Jl. Yos Sudarso km. 8 Rumbai, Pekanbaru, Telp. (0761) 52324 \\ Email: fauziahira96@gmail.com, gusneli@unilak.ac.id, shanti@unilak.ac.id
}

\begin{abstract}
ABSTRAK
Beton yang telah diaduk dengan waktu yang berlebihan dilokasi dan dibawa dengan mobil ready mix terkadang membutuhkan waktu yang cukup lama dalam pembongkaran sehingga akan membuat mutu beton berkurang. Maka tujuan dari penelitian ini adalah untuk mengetahui pengaruh variasi penambahan bahan aditif Consol SG terhadap kuat tekan beton. Consol SG berfungsi untuk mengurangi jumlah air dan memperlambat proses pengeringan. Benda uji yang digunakan berbentuk silinder ukuran $15 \mathrm{~cm} \mathrm{x} 30 \mathrm{~cm}$. Pada penelitian digunakan variasi penambahan Consol SG sebanyak 0\%, 0,10\%, 0,30\%, 0,50\%, 0,80\%, $1,00 \%$, dan 1,20\%. Berdasarkan hasil pengujian yang telah dilakukan dengan dan tanpa penambahan Consol SG, maka diperoleh hasil pengujian kuat tekan beton pada seluruh benda uji lebih tinggi dari pada kuat tekan beton rencana yaitu K-225. Nilai kuat tekan rata-rata paling tinggi diperoleh pada persentase penambahan Consol SG 1,00\%, yaitu $361,37 \mathrm{Kg} / \mathrm{cm}^{2}$. Analisis data dilakukan dengan analisis statistik dan analisis regresi. Berdasarkan pengujian ANAVA didapatkan $\mathrm{F}_{\text {hitung }}=6,1267$ dimana lebih besar dari $\mathrm{F}_{0,05}=2,85$ dan $\mathrm{F}_{0,01}=$ 4,46 ini memperjelas bahwa terdapat interaksi atau perlakuan sangat nyata antara kuat tekan beton dengan penambahan bahan aditif Consol SG. Model regresi yang dihasilkan berbentuk regresi polinomial derajat 2 persamaannya adalah $\mathrm{y}=-116,27 \mathrm{x}^{2}+202,44 \mathrm{x}+244$ dengan nilai $\mathrm{R}^{2}=0,5663$.
\end{abstract}

Kata Kunci: Beton, Consol SG, Kuat Tekan

\begin{abstract}
Concrete that has been stirred with excessive time in a location and brought in the ready-mix sometimes takes a long time in dismantling so it will make the quality of concrete is reduced. On that basis, the purpose of this research is to know the influence of variation of an addition of additive material of Consol SG to the compressive strength of concrete. Consol SG serves to reduce the amount of water and slow the drying process. The test specimens used are cylindrical in size $15 \mathrm{~cm} \times 30 \mathrm{~cm}$. In the study used variations of the addition of Consol SG as much 0\%,0,10\%,0,30\%, 0,50\%, 0,80\%, 1,00\%, and 1,20\%. Data analysis was done by statistical analysis and regression analysis. Based on the results of tests that have been done with and without the addition of Consol SG, concrete strength test results obtained on all test specimens higher than the compressive strength of the concrete plan that is $K-225$. The highest value of compressive strength is obtained at the percentage of addition of Consol SG 1,00\%, that is $361,37 \mathrm{Kg} / \mathrm{cm}^{2}$. Data analysis was performed by statistical analysis and regression analysis. Based on ANAVA testing obtained $F_{\text {hitung }}=6,1267$ which is greater than $F_{0,05}=2,85$ dan $F_{0,01}=4,46$ this makes it clear that there is a very real interaction or treatment between the compressive strength of concrete and the addition of Consol SG additives. The regression model produced in the form of regression polynomial of degree 2 equation is $y=-116,27 x^{2}+$ $202,44 x+244$ with value $R^{2}=0,5663$.
\end{abstract}

Keywords: Concrete, Consol SG, Compressive Strength

\section{PENDAHULUAN}

Material beton yang digunakan pada konstruksi terdiri dari semen, air, pasir (agregat halus) dan kerikil (agregat kasar) yang dicampur dengan perbandingan tertentu dan untuk menghasilkan kekuatan tertentu pula. Kekuatan yang diukur pun biasanya hanya kuat tekannya saja yang diuji pada standar umur 28 hari. Beton yang dibuat secara konvensional umumnya mempunyai kuat tekan antara $18-32 \mathrm{MPa}\left(\mathrm{N} / \mathrm{mm}^{2}\right)$ dan berat $2,4 \mathrm{ton} / \mathrm{m}^{3}$, biasanya disebut sebagai beton normal atau konvensional, sedangkan beton yang mempunyai kuat tekan di atas $35 \mathrm{MPa}$ biasanya disebut dengan beton mutu tinggi.

Selain kualitas dan gradasi agregat halus dan kasar, kualitas beton yang dibuat juga bergantung pada nilai perbandingan berat penggunaan air 
dengan semen, yang disebut sebagai Faktor Air Semen (FAS). Nilai FAS ini juga akan mempengaruhi tingkat kemudahan pengerjaan (workability) dari beton yang dibuat.

Beton yang telah diaduk dengan waktu yang berlebihan dilokasi dan dibawa dengan mobil ready mix dan terkadang membutuhkan waktu yang lama pula dalam pembongkaran sehingga akan membuat mutu beton berkurang. Adapun faktor yang menyebabkan waktu yang lama dalam pengadukan adalah perjalanan yang macet, lokasi pembongkaran yang sulit dijangkau antara mobil yang satu dengan lainnya, bahkan kondisi pompa yang terkadang belum siap serta faktor lain yang menyebabkan kondisi beton tidak maksimal.

Seiring berkembangnya teknologi, sekarang ini telah banyak bahan tambah (admixture) yang dapat membantu menjaga kualitas dan kelecakan (workability) pada beton. Namun perlu diperhatikan juga dalam memilih bahan tambah (admixture), sesuai dengan situasi dan kondisi beton yang telah direncanakan. Dimana pemakaian bahan tambah perlu diperhatikan volume takaran yang sesuai dengan rencana. Pemakaian bahan tambah (admixture) akan tidak ekonomis apabila digunakan berlebihan.

Dalam upaya mengganti sebagian bahan dari material utama penyusun beton dengan bahan tambah zat kimia, peneliti mencoba melakukan penelitian variasi persentase penambahan yang optimum dengan penambahan bahan aditif Consol SG terhadap uji kuat tekan K-225.

\section{METODE PENELITIAN}

\section{Lokasi dan Waktu Penelitian}

Penelitian ini dilaksanakan di Laboratorium Batching Plant PT. RMB (Riau Mas Bersaudara), Jalan Raya Pekanbaru-Bangkinang KM. 24, Delima, Tampan, Kota Pekanbaru, Riau.

\section{Bahan dan Alat Penelitian}

1. Bahan

Bahan-bahan yang digunakan dalam penelitian ini adalah sebagai berikut :

a. Semen portland type I (Ordinary Portland Cement/OPC), produksi PT. Semen Padang.

b. Agregat kasar berupa batu alam (coral) berasal dari batu bersurat, candi muara takus.

c. Agregat halus berupa olahan crusher yang berasal dari batu bersurat, candi muara takus.

d. Bahan aditif Consol SG dari PT. Concrete Technology Indonesia.

e. Air yang digunakan adalah air bersih pada Laboratorium Batching Plant PT. Riau Mas Bersaudara.

2. Alat Penelitian
Dalam melakukan penelitian dengan eksperimen ini maka diperlukan alat-alat sebagai berikut:

a. Timbangan dengan ketelitian $0,1 \%$

b. Kerucut Abrams yang digunakan untuk pengujian Slump

c. Tongkat Pemadat

d. Sendok spesi

e. Mistar perata

f. Gelas ukur

g. Ember

h. Skop

i. Oven

j. Mesin penguncang saringan

k. Saringan agregat

1. Cetakan Silinder (ukuran 30x15 cm)

m. Bak untuk merendam benda uji

n. Piknometer dengan kapasitas $500 \mathrm{ml}$

o. Molen

p. Mesin uji kuat tekan beton

\section{Rancang Perlakuan}

Pada penelitian ini dilakukan dengan menggunakan variasi perbandingan yaitu penambahan Consol SG yang masing-masing variasi sebanyak 3 (tiga) sampel benda uji.

Pembuatan benda uji dibuat berdasarkan perhitungan proporsi campuran dari hasil rancangan campuran beton (mix design). Pembuatan benda uji $\mathrm{K}-225$ ini mengacu pada metode DoE (Departmen of Environment) dan Standar Nasional Indonesia (SNI 03-2493-1991) tentang Metode Pembuatan dan Perawatan Benda Uji Beton K-225 di Laboratorium. Pembuatan benda uji dilakukan untuk menentukan kuat tekan dengan umur beton 28 hari.

Sampel benda uji yang direncanakan berbentuk silinder dengan jumlah benda uji sebanyak 21 buah. Setelah didapat rencana campuran beton, untuk persentase pemakaian Consol SG bervariasi terhadap berat semen. tabel 1 .

Adapun rincian benda uji dapat dilihat pada Tabel 1 Pembuatan dan perawatan benda uji

\begin{tabular}{|c|c|c|c|c|c|c|c|c|}
\hline \multirow{2}{*}{$\begin{array}{c}\text { Benda } \\
\text { Uji }\end{array}$} & \multicolumn{7}{|c|}{ Persentase Benda Uji } & \multirow{2}{*}{$\begin{array}{c}\text { Total } \\
\text { Sampel }\end{array}$} \\
\hline & 0 & 0,1 & 0,3 & 0,5 & 0,8 & 1,0 & 1,2 & \\
\hline $\begin{array}{c}\text { Consol } \\
\text { SG }\end{array}$ & 3 & 3 & 3 & 3 & 3 & 3 & 3 & 21 \\
\hline
\end{tabular}

(Sumber : Hasil penelitian, 2018)

\section{Pencampuran dan pencetakan sampel}

Adukan beton yg telah merata kemudian dicampur dengan bahan tambah aditif Consol SG sampai campuran tersebut merata (homogen). Setelah pencampuran beton selesai dituang kedalam tempat cetakan yang berbentuk silinder yang telah diolesi dengan oli. Kemudian benda uji dibiarkan hingga kering, dan setelah itu dibuka dari cetakan untuk dilakukan perawatan kedalam bak curing.

2. Pengujian kuat tekan 
Kuat tekan beton merupakan gambaran mutu beton, karena biasanya kenaikan kuat tekan beton akan diikuti oleh perbaikan sifat beton yang lainnya.Menurut SNI 03-1974-1990 yang dimaksud dengan kuat tekan beton adalah besarnya beban persatuan luas, yang menyebabkan benda uji beton hancur bila dibebani dengan gaya tertentu, yang dihasilkan oleh mesin uji tekan. Pengujian kuat tekan beton dilakukan dengan cara memberi gaya tekan aksial secara bertahap terhadap benda uji, sampai benda uji mengalami keruntuhan. Besarnya kuat tekan beton dapat dihitung dengan cara membagi beban maksimum pada saat benda uji hancur dengan luas penampang benda uji. Kuat tekan beton tersebut dapat dicari dengan menggunakan :

$$
\mathrm{Fc}=\frac{\mathrm{P}}{\mathrm{Ac}}
$$

Keterangan:

Fc = Kuat tekan beton $(\mathrm{MPa})$

$\mathrm{P} \quad=$ Pembacaan beban $(\mathrm{KN})$

$\mathrm{A}_{\mathrm{c}} \quad=$ Luas penampang $\left(\mathrm{mm}^{2}\right)$

\section{HASIL DAN PEMBAHASAN}

Hasil

Hasil pengujian material yang akan dibahas dalam penelitian ini adalah hasil dari pengujian agregat halus (olahan crusher yang berasal dari batu bersurat, candi Muara Takus) dan agregat kasar (batu alam yang berasal dari batu bersurat, candi Muara Takus).

1. Hasil dan pemeriksaan agregat halus

Pada penelitian ini agregat halus yang dipakai adalah olahan crusher yang berasal dari batu bersurat, candi Muara Takus. Dari pemeriksaan agregat halus maka di dapat hasil sebagai berikut :

a. Hasil pemeriksaan berat jenis dan penyerapan agregat halus

1) Berat jenis kering (bulk spesicifik gravity) merupakan perbandingan dari berat agregat kering dan berat air yang isinya sama dengan isi agregat dalam keadaan jenuh pada suhu tertentu. Dari hasil pemeriksaan didapat nilai $\mathrm{BJ}$ kering $=2,595$, hasil pengujian memenuhi persyaratan SNI yaitu berat jenis minimal 2,5.

2) Berat jenis kering permukaan (SSD) merupakan perbandingan antara agregat kering permukaan jenuh dengan air suling yang permukaannya sama dengan berat agregat dalam keadaan jenuh pada suhu tertentu. Dari hasil pemeriksaan didapat nilai $\mathrm{BJ}$ SSD $=2,607$, hasil pengujian memenuhi persyaratan SNI yaitu berat jenis minimal 2,5.
3) Berat jenis semu (apparent) merupakan perbandingan antara agregat kering dan berat air suling yang isinya sama dengan isi agregat dalam keadaan kering pada suhu tertentu. Dari hasil pemeriksaan didapat nilai $\mathrm{BJ}$ semu $=2,627$, hasil pengujian memenuhi persyaratan SNI yaitu berat jenis minimal 2,5.

4) Penyerapan adalah persentase berat air yang dapat diserap pori-pori terhadap berat agregat kering. Dari hasil pemeriksaan diperoleh nilai penyerapan $0,47 \%$, hasil pengujian memenuhi persyaratan SNI yaitu penyerapan maksimal $5 \%$.

b. Hasil pemeriksaan berat isi agregat halus

Berat isi agregat adalah perbandingan antara berat agregat dengan volume yang ditempatinya, hasil pemeriksaan berat isi agregat halus diperoleh :

1) Berat isi lepas $=1,173 \mathrm{~kg} / \mathrm{lt}$

2) Berat isi padat $=1,275 \mathrm{~kg} / \mathrm{lt}$

Agregat yang diuji memenuhi persyaratan SNI yaitu berat isi minimum $1,222 \mathrm{~kg} / \mathrm{lt}$.

c. Hasil pemeriksaan bahan lolos saringan No. 200 agregat halus

Pemeriksaan bahan lolos saringan No.200 bertujuan untuk mengetahui nilai kadar lumpur agregat halus. Berdasarkan pemeriksaan bahan lolos saringan No.200 diperoleh nilai kadar lumpur sebesar $1,00 \%$, hasil pengujian memenuhi syarat SNI yaitu nilai kadar lumpur maksimum 5\%. Hasil pengujian bahan lolos saringan No.200 pada agregat halus dapat dilihat pada tabel 2.

Tabel 2 Hasil pemeriksaan bahan lolos saringan No.200 agregat halus

\begin{tabular}{|c|c|c|}
\hline Pemeriloum & Bendatin $1(\mathrm{~g})$ & Bende $\mathrm{V}$ i $2(\mathrm{~m})$ \\
\hline Bendu Uyinaval (A) & $\$ 00,00$ & 900,00 \\
\hline Bend Lji Tertahan AYakanNa 300 (B) & 494,00 & 494,10 \\
\hline kader luapue (WA)-(B)/ $/(\mathbf{A}) \times 10 \mathrm{ch}$ & $1,01 \%$ & espt. \\
\hline Kulur tumpur Ruts-nes & \multicolumn{2}{|l|}{1.0} \\
\hline
\end{tabular}

(Sumber : Hasil penelitian, 2018)

d. Hasil pemeriksaan kadar air agregat halus

Kadar air agregat adalah perbandingan antara berat air yang dikandung agregat dengan berat dalam keadaan kering. Dari hasil pengujian pemeriksaan kadar air agregat halus diperoleh nilai $6,43 \%$. Hasil dari pemeriksaan kadar air agregat halus dapat dilihat pada tabel 3 .

Tabel 3 Hasil pemeriksaan kadar air agregat halus

\begin{tabular}{|c|c|c|c|}
\hline Berat eawan & $(w 1)$ & 535,00 & $\mathrm{Cr}$ \\
\hline Berat eawan + Tamah basal & (w2) & 5535,00 & $\mathrm{Or}$ \\
\hline Berat eawan - Tamah kering & $(w)$ & 5233,00 & Or \\
\hline Massa Air & $A=w 2-w_{3}^{3}$ & 302,00 & Ot \\
\hline Mama Tanah krring. & $B=w 3-w 1$ & 4608,00 & Gr \\
\hline Kadat ait & $\mathbf{W}=\mathbf{A B} \cdot 100 \%$ & 6,43 & 5 \\
\hline
\end{tabular}

(Sumber : Hasil penelitian, 2018) 
e. Hasil pemeriksaan kotoran organik agregat halus

Dari hasil pemeriksaan kotoran agregat halus didapatkan perbandingan warna benda uji dalam botol sesuai dengan nomor 2 pada pelat standar warna organik. Agregat halus dapat digunakan untuk campuran beton sesuai dengan standar SNI yaitu kotoran organik maksimum pada pelat standar warna organik nomor 3 .

f. Hasil pemeriksaan analisa saringan agregat halus

Analisa saringan bertujuan untuk menentukan pembagian butir (gradasi) agregat halus dengan menggunakan saringan untuk memperoleh distribusi besaran jumlah persentasi butiran agregat halus. Agregat halus yang digunakan dalam penelitian ini digolongkan pada daerah IV yang memiliki butiran pasir agak halus.

2. Hasil dan pemeriksaan agregat kasar

Agregat kasar yang digunakan dalam penelitian ini adalah batu alam yang berasal dari batu bersurat, candi Muara Takus. Adapun hasil dari pemeriksaan agregat kasar yang diperoleh adalah sebagai berikut :

a. Hasil pemeriksaan berat jenis dan penyerapan agregat kasar

1) Berat jenis kering (bulk spesicifik gravity) merupakan perbandingan berat agregat kering dan berat air yang isinya sama dengan isi agregat dalam keadaan jenuh pada suhu tertentu. Dari hasil pemeriksaan didapat nilai $\mathrm{BJ}$ kering $=2,572$, hasil pengujian memenuhi persyaratan SNI yaitu berat jenis minimal 2,5.

2) Berat jenis kering permukaan (SSD) merupakan perbandingan antara agregat kering permukaan jenuh dengan air suling yang permukaannya sama dengan berat agregat dalam keadaan jenuh pada suhu tertentu. Dari hasil pemeriksaan didapat nilai $\mathrm{BJ}$ SSD $=2,614$, hasil pengujian memenuhi persyaratan SNI yaitu berat jenis minimal 2,5.

3) Berat jenis semu (apparent) merupakan perbandingan antara agregat kering dan berat air suling yang isinya sama dengan isi agregat dalam keadaan kering pada suhu tertentu. Dari hasil pemeriksaan didapat nilai $\mathrm{BJ}$ semu $=2,686$, hasil pengujian memenuhi persyaratan SNI yaitu berat jenis minimal 2,5.

4) Penyerapan adalah persentase berat air yang dapat diserap pori-pori terhadap berat agregat kering. Dari hasil pemeriksaan diperoleh nilai penyerapan $1,65 \%$, hasil pengujian memenuhi persyaratan SNI yaitu penyerapan maksimal $3 \%$. b. Hasil pemeriksaan berat isi agregat kasar

Berat isi agregat adalah perbandingan antara berat agregat dengan volume yang ditempatinya, hasil pemeriksaan berat isi agregat kasar diperoleh :
1) Berat isi lepas $\quad=1,07 \mathrm{~kg} / \mathrm{lt}$
2) Berat isi padat $=1,25 \mathrm{~kg} / \mathrm{lt}$

c. Hasil pemeriksaan bahan lolos saringan No. 200 agregat kasar

Pemeriksaan bahan lolos saringan No.200 bertujuan untuk mengetahui nilai kadar lumpur agregat kasar. Lumpur yang terdapat dalam agregat kasar berasal dari tanah ikutan yang menempel pada agregat. Berdasarkan pemeriksaan bahan lolos saringan No.200 diperoleh nilai kadar lumpur sebesar 0,96\%, hasil pengujian memenuhi syarat SNI yaitu nilai kadar lumpur maksimum $1 \%$. $\%$. Hasil pengujian bahan lolos saringan No.200 pada agregat kasar dapat dilihat pada tabel 4 .

Tabel 4 Hasil pemeriksaan bahan lolos saringan No.200 agregat kasar

\begin{tabular}{|c|c|c|c|}
\hline Peminikzazan & Hends Lip 1 & Bends U. 2 & Sanuan \\
\hline Benda uĩ awd (A) & 1000,00 & 1000.00 & Or \\
\hline Benda wii tertahan aykan no 200 (B) & 991,70 & 989.30 & Gr \\
\hline lade fuanpar $=(\mathbf{A})-(\mathbf{D}) \times 100 \%$. & 0.4 & 1.08 & $\star$ \\
\hline Kader liangur ats - rata & \multicolumn{2}{|c|}{2.6} & 4 \\
\hline
\end{tabular}

(Sumber : Hasil penelitian, 2018)

d. Hasil pemeriksaan keausan agregat kasar dengan mesin los anglos

Pengujian ini bertujuan untuk menentukan ketahanan agregat kasar terhadap keausan dengan mempergunakan mesin los angelos. Keausan tersebut dinyatakan dengan perbandingan anatara berat bahan aus lewat saringan no.12 terhadap berat semula. Hasil pemeriksaan keausan agregat kasar dapat dilihat pada tabel 5 .

Tabel 5 Hasil pemeriksaan keausan agregat kasar

\begin{tabular}{|l|c|c|}
\hline \multicolumn{1}{|c|}{ Pengujian } & Sampel & Satuan \\
\hline Benat tempat + contohawal $(\mathrm{A})$ & 5000 & Gram \\
\hline Berat tempat + contoh akhir (B) & 3351 & Oram \\
\hline Keausan agregat lasar = $\{(\mathrm{A}-\mathrm{B})(\mathrm{A})\} \times 1006$ & 32,98 & 5 \\
\hline
\end{tabular}

(Sumber : Hasil penelitian, 2018)

Hasil pemeriksaan keausan agregat kasar menggunakan langkah type $\mathrm{C}$ dengan bola-bola sebanyak 8 buah, maka diperoleh nilai keausan abrasi 32,98 \%, hasil pengujian memenuhi persyaratan SNI yaitu maksimum $50 \%$.

e. Hasil pemeriksaan analisa saringan agregat kasar

Setelah melakukan analisis saringan agregat kasar, persentase lolos melalui komulatif membuktikan bahwa agregat kasar yang digunakan 
dalam adukan beton gradasi agregat adalah: distribusi ukuran butiran agregat sebagai pernyataan dari nilai gradasi dipakai persentase dari berat butiran yang tertinggal atau lewat di dalam suatu susunan ayakan.

\section{Perencanaan Campuran Beton (Mix Design)}

Dalam pencampuran bahan beton, metode yang digunakan pada penelitian ini adalah metode DoE (Department of Envirovment). Pada rancangan campuran ini, direncanakan beton K-225 dengan penambahan bahan aditif Consol SG, dengan variasi $0 \%-1,2 \%$, sehingga total sampel 21 buah.

Hasil data pengujian terhadap agregat halus dan kasar dari PT. Riau Mas Bersaudara dapat diperoleh campuran beton dengan data-data yang ada sebagai berikut :

1. Kuat tekan beton yang diisyaratkan $=\frac{225}{10} \times 0,83$ $=18,675 \mathrm{MPa}$.

2. Ukuran maksimal agregat kasar $=20 \mathrm{~mm}$

3. Standar deviasi $=4,2 \mathrm{MPa}$ (mutu pengendalian baik)

4. Slump rencana $=12 \mathrm{~cm}$

5. Semen yang digunakan $=$ Semen portland type I (OPC)

6. Agregat kasar yang digunakan = Coral (batu alam)

7. Agregat halus = Crusher zona II (pasir agak kasar)

8. Hasil pemeriksaan laboratorium diperoleh data pada tabel 6 .

Tabel 6 Hasil pemeriksaan agregat

\begin{tabular}{|l|c|c|}
\hline \multicolumn{1}{|c|}{ Analisa } & Kasar & Halus \\
\hline BJ SSD & 2,614 & 2,607 \\
\hline Kadar Air & $1,39 \%$ & $6,43 \%$ \\
\hline Penyerapan & $1,65 \%$ & $0,47 \%$ \\
\hline Komposisi Campuran & $57,885 \%$ & $42,115 \%$ \\
\hline
\end{tabular}

(Sumber : Hasil penelitian, 2018)

Mix design :

1. Kuat tekan beton yang diisyaratkan $18,675 \mathrm{MPa}$ pada beton umur 28 hari.

2. Standar deviasi $=4,2 \mathrm{MPa}$ (mutu pengendalian baik).

3. Nilai tambah (margin) berdasarkan catatan deviasi standar diperoleh :

$$
\begin{aligned}
\mathrm{m} & =\mathrm{k} \mathrm{x} \mathrm{sd} \\
& =1,64 \times 4,2 \\
& =6,89 \mathrm{MPa}
\end{aligned}
$$

4. Nilai kuat tekan beton yang hendak dicapai

$$
\begin{aligned}
\mathrm{fcr}^{\prime} & =\mathrm{fc}{ }^{\prime}+\mathrm{m} \\
& =18,675 \mathrm{MPa}+6,89 \mathrm{MPa} \\
& =25,565 \mathrm{MPa}
\end{aligned}
$$

5. Semen yang digunakan semen Padang tipe I (OPC).

6. Agregat yang digunakan adalah agregat kasar dan halus alami.
7. Penetapan faktor air semen :

Faktor air semen ditetapkan sebesar 0,655

8. Penetapan faktor air semen maksimum

Berdasarkan persyaratan FAS maksimum untuk mencapai pembebanan pada tabel persyaratan FAS maksimum diperoleh FAS maksimum 0,60 beton didalam ruangan bangunan keadaan keliling non korosif.

9. Penentuan nilai slump telah ditetapkan sebesar $12 \mathrm{~cm}$.

10. Ukuran maksimum butir agregat $20 \mathrm{~mm}$.

11. Penetapan jumlah air yang diperlukan permeter kubik $\left(\mathrm{m}^{3}\right)$ berdasarkan ukuran maksimum nilai slump yang diinginkan dengan bantuan tabel perkiraan kebutuhan air per $\mathrm{m}^{3}$ diperoleh jumlah air yang diperlukan $=215$ liter.

$A=(2 / 3 \times 215)+(1 / 3 \times 215)$

$\mathrm{A}=215$ liter

12. Menghitung berat semen yang diperlukan

Berat semen per- $\mathrm{m}^{3}$ beton dihitung dengan membagi jumlah air dari langkah 11 dengan FAS yang diperoleh dari langkah 7 dan 8, yaitu diambil nilai FAS 0,655

Maka berat semen $=\frac{215}{0,655}=328 \mathrm{Kg} / \mathrm{m}^{3}$

13. Kebutuhan semen minimum

Berdasarkan tabel kebutuhan semen minimum untuk berbagai pembebanan dan lingkungan khusus, maka diperoleh sebesar $=275 \mathrm{~kg} / \mathrm{m}^{3}$, kondisi beton di dalam ruangan keadaan keliling non korosif.

14. Penyesuaian kebutuhan semen.

Diambil nilai terbesar dari langkah 12 dan 13, maka diambil berat semen $=328 \mathrm{~kg} / \mathrm{m}^{3}$.

15. Kebutuhan air tetap atau nilai FAS

Karena tidak ada perubahan pada jumlah semen yang dihitung pada langkah 12, maka tidak ada penyesuaian jumlah air maupun FAS, jadi kebutuhan air tetap 215 liter, dan FAS 0,655.

16. Berat jenis campuran pasir dan coral

Berdasarkan hasil penelitian laboratorium diperoleh BJ SSD agregat halus = 2.607, BJ SSD agregat kasar $=2,614$

Maka BJ campuran diperoleh dengan rumus : $=(57,885 \%$ x BJ ssd kasar $)+(42,115 \%$ x BJ ssd halus)

$$
=(57,885 \% \times 2,614)+(42,115 \% \times 2,607)
$$$$
=2,611
$$

17. Penentuan berat jenis beton Dengan data BJ agregat dan kebutuhan air per$\mathrm{m}^{3}$ dan dibantu dengan grafik hubungan kandungan air, berat jenis agregat campuran dan berat beton diperoleh $\mathrm{BJ}$ beton $=2350$

18. Kebutuhan agregat campuran pasir dan kerikil Berat agregat campuran $=\mathrm{W}$ beton $-\mathrm{Pc}-$ Air $=2350-328-215$ $=1807 \mathrm{~kg} / \mathrm{m}^{3}$

19. Jumlah agregat halus 
Presentase pasir telah diketahui sebesar 42,115\%, maka :

$$
\begin{array}{ll}
\text { W pasir } & =42,115 \% \times \text { W camp } \\
& =42,115 \% \times 1807 \mathrm{~kg} / \mathrm{m}^{3} \\
& =761,018 \mathrm{~kg} / \mathrm{m}^{3}
\end{array}
$$

20. Jumlah agregat kasar

Dihitung dengan cara mengurangi kebutuhan agregat campuran dengan kebutuhan pasir.

$$
\begin{array}{ll}
\text { W split } & =\mathrm{W} \text { camp }-\mathrm{W} \text { pasir } \\
& =1807-761,018 \\
& =1045,982 \mathrm{~kg} / \mathrm{m}^{3}
\end{array}
$$

Jadi berdasarkan mix design, diperoleh jumlah komposisi campuran untuk beton per $\mathrm{m}^{3}$ beton segar sebagai berikut :
1. Semen
$=328 \mathrm{~kg}$.
2. Air
$=215$ liter
3. Pasir (Ps)
$=761,018 \mathrm{~kg}$.
4. Kerikil/split $(\mathrm{Kr})$
$=1045,982 \mathrm{~kg}$

5. Persentase Consol SG $=0,0 \%, 0,1 \%, 0,3 \%$, $0,5 \%, 0,8 \%, 1,0 \%, 1,2 \%$ (terhadap berat semen).

Sedangkan kebutuhan material untuk balok ukuran $(15$ x 30$) \mathrm{cm}$ sebanyak 3 sampel benda uji yaitu :
1. Volume silinder $=\pi \times r^{2} \times t$
$=\pi \times 0,075^{2} \times 0,30$
$=0,0053 \mathrm{~m}^{3}$.

2. Faktor gembur $=$ (Faktor gembur agregat halus + Faktor gembur agregat kasar)/2

$=(1,173+1,070) / 2$

$=1,122$

3. Semen

$=(\mathrm{Pc} x$ Vol. silinder $\mathrm{x}$ Faktor gembur) $\mathrm{x} 3$

$=(328 \times 0,0053 \times 1,122) \times 3$

$=5,852 \mathrm{~kg}$

4. Pasir

5. Kerikil

6. Air

$=($ Ps $\mathrm{x}$ Vol. silinder $\mathrm{x}$ Faktor gembur) $\times 3$

$=(761,018 \times 0,0053 \times 1,122)$ x 3

$=13,576 \mathrm{~kg}$

$=(\mathrm{Kr} \times$ Vol. silinder $\mathrm{x}$ Faktor gembur) $\mathrm{x} 3$

$=(1045,982 \times 0,0053 \times$ $1,122) \times 3$

$=18,660 \mathrm{~kg}$

$=($ Air $\mathrm{x}$ Vol. silinder $\mathrm{x}$ faktor gembur) $\mathrm{x} 3$

$=(215 \times 0,0053 \times 1,122) \times 3$

$=3,836 \mathrm{~kg}$

\section{Hasil Pengujian Kuat Tekan}

Adapun nilai kuat tekan didapatkan dari ratarata hasil penelitian, dengan sampel benda uji silinder $15 \times 30 \mathrm{~cm}$ untuk umur beton 28 hari dengan variasi penambahan Consol SG, maka hasil penelitian yang telah dilakukan dapat dilihat pada tabel 7.

Tabel 7 Uji kuat tekan rata-rata beton umur 28 hari

\begin{tabular}{|c|c|}
\hline $\begin{array}{c}\text { Consol SG } \\
(\%)\end{array}$ & $\begin{array}{c}\text { Rata-rata } \\
\left(\mathrm{Kg} / \mathrm{cm}^{2}\right)\end{array}$ \\
\hline 0 & 272,18 \\
\hline 0,1 & 257,13 \\
\hline 0,3 & 244,39 \\
\hline 0,5 & 321,99 \\
\hline 0,8 & 349,79 \\
\hline 1,0 & 361,37 \\
\hline 1.2 & 291,87 \\
\hline
\end{tabular}

(Sumber : Hasil penelitian, 2018)

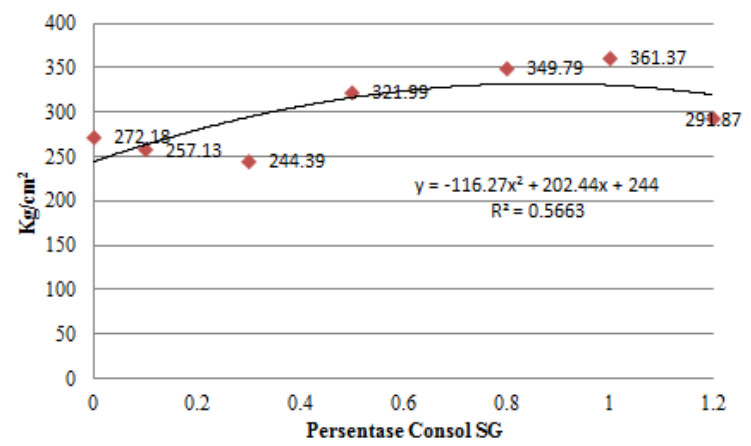

Gambar 1. Grafik kuat tekan beton umur 28 hari (Sumber : Hasil penelitian, 2018)

\section{Analisis Statistik}

Teknik Statistik yang dikenal juga dengan analisa ragam (analisis of variance) adalah suatu teknik menguraikan keragaman total dalam suatu komponen-komponen untuk memudahkan analisis dan interpretasi data hasil percobaan. Analisis statistik digunakan untuk menjawab Hipotesis pada penelitian ini, yaitu penambahan limbah serat kawat tunggal pada beton.

Langkah-langkah pengerjaan analisis statistik adalah:

1. Menentukan notasi matematika (rancang perlakuan) :

Untuk menyimpulkan perlakuan mana yang menghasilkan kuat lentur yang lebih baik, maka data harus dianalisis terlebih dahulu, disesuaikan antara rancangan perlakukan dengan notasi matematika dan data yang sebenarnya.

Tabel 8 Notasi matematika dan data sebenarnya

\begin{tabular}{|c|c|c|c|c|c|}
\hline \multirow{2}{*}{ Perlakuan (i) } & \multicolumn{3}{|c|}{ Ulangan (j) } & \multirow{2}{*}{ Jumlah } & \multirow{2}{*}{ Satuan } \\
\cline { 2 - 4 } & 1 & 2 & 3 & & \\
\hline $0 \%$ & 284,93 & 267,55 & 264,08 & 816,56 & $\mathrm{Kg} / \mathrm{cm}^{2}$ \\
\hline $0,10 \%$ & 236,28 & 250,18 & 284,93 & 771,39 & $\mathrm{Kg} / \mathrm{cm}^{2}$ \\
\hline $0,30 \%$ & 250,18 & 243,23 & 239,75 & 733,16 & $\mathrm{Kg} / \mathrm{cm}^{2}$ \\
\hline $0,50 \%$ & 326,62 & 333,57 & 305,77 & 965,96 & $\mathrm{Kg} / \mathrm{cm}^{2}$ \\
\hline $0,80 \%$ & 368,32 & 312,72 & 368,32 & 1049,36 & $\mathrm{Kg} / \mathrm{cm}^{2}$ \\
\hline $1,00 \%$ & 382,22 & 333,57 & 368,32 & 1084,11 & $\mathrm{Kg} / \mathrm{cm}^{2}$ \\
\hline $1,20 \%$ & 340,52 & 319,67 & 215,43 & 875,62 & $\mathrm{Kg} / \mathrm{cm}^{2}$ \\
\hline Jumlah & 2189,07 & 2060,49 & 2046,60 & 6296,16 & $\mathrm{Kg} / \mathrm{cm}^{2}$ \\
\hline
\end{tabular}

(Sumber : Hasil penelitian, 2018) 
2. Menentukan derajat bebas :

Diketahui :

Jumlah perlakuan $(\mathrm{t})=7$

Pengulangan $(\mathrm{r}) \quad=3$

Maka :

$$
\begin{array}{ll}
\mathrm{Db}_{\text {perlakuan }} & =(\mathrm{t}-1)=(7-1)=6 \\
\mathrm{Db}_{\text {percobaan }} & =\mathrm{t}(\mathrm{r}-1)=7(3-1)=14
\end{array}
$$

3. Menghitung faktor koreksi

$$
\mathrm{Fk}=\frac{\mathrm{Y}^{2}}{\mathrm{r} . \mathrm{t}}=\frac{6296,16^{2}}{3 \times 7}=1887696,702
$$

4. Menghitung jumlah kuadrat total

$$
\begin{aligned}
\mathrm{JK}_{\text {total }}= & \sum_{\mathrm{i}=1}^{\mathrm{t}} \sum_{\mathrm{j}=1}^{\mathrm{r}} \mathrm{Y}_{\mathrm{ij}}{ }^{2}-\mathrm{Fk} \\
= & \left(284,93^{2}+267,55^{2}+264,08^{2}+\right. \\
& 236,28^{2}+250,18^{2}+284,93^{2}+ \\
& 250,18^{2}+243,23^{2}+239,75^{2}+ \\
& 326,62^{2}+333,57^{2}+305,77^{2}+ \\
& 368,32^{2}+312,72^{2}+368,32^{2}+ \\
& 382,22^{2}+333,57^{2}+368,32^{2}+ \\
& 340,52^{2}+319,67^{2}+215,43^{2}- \\
& 1887696,702 \\
= & 51775,4206
\end{aligned}
$$

5. Menghitung jumlah kuadrat perlakuan

$$
\begin{aligned}
& \mathrm{JK}_{\text {Perlakuan }}=\sum_{\mathrm{i}=1}^{\mathrm{t}} \frac{\mathrm{Y}_{\mathrm{i}}^{2}}{\mathrm{r}}-\mathrm{Fk} \\
& \begin{array}{c}
816,56^{2}+771,39^{2}+733,16^{2}+965,96^{2}+ \\
1049,36^{2}+1084,11^{2}+875,62^{2}
\end{array} \\
& \frac{-1887696,702}{=} \\
& =37495,4177
\end{aligned}
$$

6. Menghitung jumlah kuadrat galat

$\mathrm{JK}_{\mathrm{G} . P e r c}=\mathrm{JK}_{\text {total }}-\mathrm{JK}_{\text {perl }}$

$$
=51775,4206-37495,4177
$$$$
=14280,0029
$$

7. Menghitung kuadrat tengah

$$
\begin{aligned}
\mathrm{KT}_{\text {perl }} & =\mathrm{JK}_{\text {perl }} / \mathrm{Db}_{\text {perl }} \\
& =37495,4177 / 6 \\
& =6249,2363 \\
\mathrm{KT}_{\text {perco }} & =\mathrm{JK}_{\text {perco }} / \mathrm{Db}_{\text {perco }} \\
& =14280,0029 / 14 \\
& =1020,0002
\end{aligned}
$$

8. Menghitung $F_{\text {hitung }}$

$$
\mathrm{F}_{\text {hitung }}=\mathrm{KT}_{\text {perl }} / \mathrm{KT}_{\text {perc }}
$$

$$
\begin{aligned}
& =6249,2363 / 1020,0002 \\
& =6,1267
\end{aligned}
$$

Dari tabel $\mathrm{F}$ dapat dilihat bahwa $\mathrm{F}_{0,05}=2,85$ dan untuk tabel $\mathrm{F}_{0,01}=4,46$ sedangkan $\mathrm{F}_{\text {hitung }}=$ 6,1267 karena $F_{\text {hitung }}>\mathrm{F}_{\text {tabel, maka dapat }}$ disimpulkan bahwa terdapat interaksi atau perlakuan sangat nyata antara kuat tekan beton dengan penambahan Consol SG dalam campuran beton.

\section{Pembahasan}

Pada penelitian ini beton yang direncanakan adalah 18,675 MPa dengan mix design menggunakan variasi penambahan bahan aditif consol SG $0 \%, 0,10 \%, 0,30 \%, 0,50 \%, 0,80 \%$, $1,00 \%$, dan $1,20 \%$. Pemeriksaan agregat merupakan hal terpenting dalam pembuatan beton. Hal ini dikarenakan kuat atau tidaknya beton sangat dipengaruhi oleh kondisi agregat yang digunakan selain itu juga hasil pemeriksaan agregat digunakan untuk menentukan proporsi campuran yang ideal antara material penyusun beton. Oleh sebab itu sebelum melakukan rencana campuran beton ( $m i x$ design) hal utama yang harus diperhatikan adalah keadaan agregat.

Berdasarkan data teknik PT. Concrete Technology Indonesia consol SG bertujuan untuk mengurangi air dan memperlambat proses pengeringan, dengan dosis pemakaian $0,15-0,40 \%$, akan tetapi setelah dilakukan pengujian kuat tekan beton semakin meningkat pada penambahan consol SG 0,50 .

Pada penelitian ini dilakukan analisis statistik dan analisis regresi, berdasarkan pengujian ANAVA menyimpulkan penambahan bahan aditif Consol SG pada campuran beton terdapat interaksi atau perlakuan sangat nyata antara kuat tekan beton dengan penambahan bahan aditif pada campuran beton, dan berdasarkan analisa regresi polinomial, dengan menggunakan program Microsoft Excel, model regresi yang dihasilkan berbentuk regresi polinomial derajat 2 persamaannya adalah $\mathrm{y}=$ $116,27 x^{2}+202,44 x+244$ dengan nilai $R^{2}=0,5663$.

Perbedaan penelitian ini dengan penelitian terdahulu yaitu penelitian ini bertujuan untuk mengetahui pengaruh kuat tekan beton dengan penambahan bahan aditif Consol SG, dengan variasi penambahan Consol SG sebanyak 0\%, 0,10\%, 0,30\%, 0,50\%, $0,80 \%$, 1,00\%, dan 1,20\%. Berdasarkan hasil pengujian yang telah dilakukan dengan dan tanpa penambahan Consol SG, maka diperoleh hasil pengujian kuat tekan beton pada seluruh benda uji lebih tinggi dari pada kuat tekan beton rencana yaitu K-225. Nilai kuat tekan rata-rata paling tinggi diperoleh pada persentase penambahan Consol SG $1,00 \%$, yaitu $361,37 \mathrm{Kg} / \mathrm{cm}^{2}$. 


\section{Kesimpulan}

4. KESIMPULAN DAN SARAN

Pada penelitian pengaruh variasi penambahan bahan aditif Consol SG terhadap kuat tekan beton, dapat disimpulkan bahwa :

1. Berdasarkan pengujian ANAVA didapatkan $\mathrm{F}_{\text {hitung }}=6,1267$ dimana lebih besar dari $\mathrm{F}_{0,05}=$ 2,85 dan $\mathrm{F}_{0,01}=4,46$. Hal ini memperjelas bahwa terdapat interaksi atau perlakuan sangat nyata antara kuat tekan beton dengan penambahan bahan aditif pada campuran beton.

2. Berdasarkan hasil pengujian kuat tekan beton dengan variasi persentase Consol SG terhadap berat semen $0 \%, 0,1 \%, 0,3 \%, 0,5 \%, 0,8 \%$, $1,0 \%$, dan $1,2 \%$ diperoleh hasil uji tekan maksimum pada persentase $1,0 \%$ adalah sebesar $361,37 \mathrm{Kg} / \mathrm{cm}^{2}$, sedangkan hasil uji tekan untuk persentase Consol SG 0\% adalah sebesar 272,18 Kg/cm².

3. Model regresi yang dihasilkan berbentuk polinomial derajat 2 persamaannya adalah $\mathrm{y}=$ $116,27 x^{2}+202,44 x+244$ dengan nilai $R^{2}=$ 0,5663 .

\section{Saran}

Berdasarkan hasil pembahasan diatas, adapun saran - saran dari penulis yang sifatnya membangun adalah :

1. Dalam melakukan penelitian selanjutnya, hendaknya nilai persentase penambahan bahan aditif disarankan menggunakan variasi persentase yang berbeda guna mengetahui penyebab terjadinya nilai kuat tekan yang naik turun.

2. Dalam melakukan pengujian ketelitian alat sangat menentukan untuk mendapatkan hasil pengujian yang lebih akurat.

3. Bahan - bahan penyusun beton, terutama agregat yang akan digunakan dalam pembuatan beton harus dilakukan pemeriksaan terlebih dahulu untuk memastikan apakah agregat tersebut memenuhi persyaratan.

\section{DAFTAR PUSTAKA}

[1] Antoni dan Nugraha, P. 2007. Teknologi Beton dari Material, Pembuatan, ke Beton Kinerja Tinggi. Edisi I. Yogyakarta : Andi.

[2] Asroni, A. 2010. Balok dan Plat Beton Bertulang Kinerja Tinggi. Yogyakarta : PT. Graha Ilmu.

[3] Balai Jembatan dan Bangunan Pelengkap Jalan. 2011. Pengendalian Mutu Pekerjaan Beton. Bandung : Kementerian Pekerjaan Umum.
[4] Badan Standarisasi Nasional. 2002. Tata Cara Perhitungan Struktur Beton Untuk Bangunan Gedung SNI-03-2847-2002. Bandung : BSN

[5] Badan Standarisasi Nasional. 2002. Tata Cara Pembuatan Rencana Campuran Beton Normal SNI-03-2834-2002. Bandung : BSN.

[6] Balai Penelitian dan Pengembangan Pekerjaan Umum. 1993. Tata Cara Pembuatan Rencana Campuran Beton Normal SNI-032834-1993. Bandung : Balitbang PU.

[7] Budi, L. 2011. Jenis dan Fungsi Curing / Perawatan Beton. http://listiyonobudi.blogspot.co.id/ 2011/05 /jenis- dan -fungsi-curingperawatanbeton.html.

[8] Departemen Pekerjaan Umum. 1991. Tata Cara Perhitungan Struktur Beton Untuk Bangunan Gedung SK SNI T-15-1991-03. Jakarta : Departemen PU.

[9] Hernando, F. 2009. Perencanaan Campuran Beton Mutu Tinggi dengan Penambahan Superplasticizer dan Pengaruh Penggantian Sebagian Semen dengan Fly Ash (Tugas Akhir). Pekanbaru : Teknik Sipil S1, Universitas Lancang Kuning.

[10] Megasari, S.W., Winayati. 2017. Analisis Pengaruh Penambahan Sikament-NN Terhadap Karakteristik Beton. Jurnal Teknik Sipil. Volume 3 Nomor 2. Oktober 2017 : $117-128$.

[11] Mahyar, H. 2012. Mikro Silika Sebagai Bahan Tambah Untuk Meningkatkan Kuat Tekan Beton Mutu Tinggi. Aceh : Teknik Sipil, Politeknik Negeri Lhokseumawe.

[12] Mulyono, T. 2004. Teknologi Beton . Yogyakarta : Andi. 